\title{
Selection Factors of Market Segments and Porter's Generic Marketing Strategies: Evidence from an Emerging GCC Market
}

\author{
Mansour S. M. Lotayif ${ }^{1}$ \\ ${ }^{1}$ Business Administration Department, Business College, Beni-Swef University, Egypt \\ Correspondence: Mansour S. M. Lotayif, Business Administration Department, Business College, Beni-Swef \\ University, Egypt. E-mail: Mansourlo@yahoo.com
}

Received: June 23, 2015

Accepted: July 31, 2015

Online Published: December 18, 2015

doi:10.5539/ijbm.v11n1p199

URL: http://dx.doi.org/10.5539/ijbm.v11n1p199

\begin{abstract}
The current study aims at both identifying the detailed variables behind selecting the appropriate market segment(s) and the selection of the three generic marketing strategies i.e. differentiation, focus and cost leadership. The experiences of 177 Bahraini executives working for domestic and multi-national corporations (MNCs) were utilized to achieve these objectives. Via SPSS version 21 and throughout multivariate analytical technique (e.g. multiple regression), factor analysis, and descriptive analysis the current study's three objectives and four hypotheses were tested. Based on factor analysis, the target market selection variables are loaded on four factors as proposed by Hooley and Saunders (1993). However, the title of the fourth variable becomes "regulatory, political, and environmental" instead of only "environmental factor" as in Hooley and Saunders (1993) did name in their own study. Based on Multiple Regression (MR) results, there is no significant causality relationship between demographics (i.e. type of business, ownership, experience, and size) and market factor. Meanwhile, significant causality relationships were existed between; demographics and "economic and technological factor"; demographics and "competitive factor"; and between demographics and "regulatory, political, and environmental factor". Finally, the variables for selecting each generic strategy have been determined.
\end{abstract}

Keywords: marketing strategies, differentiation strategy, focus strategy, cost leadership strategy, and porter's generic strategies, gulf cooperation council (GCC)

\section{Introduction}

Nowadays, to survive in a rapidly changing business environment, companies are compelled to explore new opportunities, formulate new strategies, and realign their organizations to new market conditions (Long, 2001). Generally, strategy is an ongoing process affect all business' aspects in order to support and grow a successful business or organization, strategy is not a thing, not a person, a meeting, a bound document, a power point presentation, a letter from the CEO in an annual report (Pugh \& Bourgeois, 2011). In this perspective, strategy could be classified into intended strategy and realized strategy. The former represent the traditional view of strategy as a statement of intent, whilst the latter views strategy as a pattern in a stream of decisions followed by Actions (Mintzberg, 1987). Not only that but also a successful strategy should fit the features of the surrounding environment in which it is implemented, therefore different strategies are required in different world markets (Baack \& Boggs, 2008), as the essence of formulating a competitive strategy is relating a company to its environment (Porter, 1980). Inevitably, strategy implementation is a critical issue requiring much more attention (Vorhies \& Morgan, 2003).

In marketing domain in particular, marketing strategy's objectives are to examine and better understand how firms develop and sustain competitive advantage, and how this leads to better firm performance outcomes (McNaughton et al., 2002). To select the segment(s) to be served is part of the comprehensive marketing strategy of the firm. Bonom and Crittenden (1988) argued that the strategic decisions most important to the marketing function are positioning and segmentation. Spitzeck and Chapman (2012); Kotler and Keller (2008); Kalafatis et al. (2000), and Hooley et al. (1998) have argued that positioning is about how the business unit delivers value to customers and their perceptions of its products and service, relative to other offerings in the market. Meanwhile, segmentation involves deciding which customer groups best fit with the chosen position (Zahay \& Griffin, 2010). To sum up, marketing strategy includes segmentation, targeting, differentiation, and positioning whilst marketing 
management includes marketing mix' programs designed for the implementation of the selected marketing strategy. That marketing strategy is driven from firm's vision, mission, core value, and core competence (El-Ansary, 2006).

Needles to say, that part of marketing strategy ought to be harmonized with brother and sister strategies of the firm such as corporate strategy, growth strategy, and other functional area of strategies like production, finance, human resource strategies, competitive strategies, e-strategy, and global strategy (El-Ansary, 2006). Literally for any and every firm, a key element of the mission statement is the definition of the competitive domain in which it will operate. Kotler (1994) suggested that the competitive domain should cover four areas: industry scope, market segment scope, vertical scope and geographical scope. For instance, the geographical scope is "defined as the range of regions, countries, or country groups where the corporation wishes to operate" (Olusoga, 1993, p. 41). Consequently, the current study is an endeavor to figure out the detailed variables behind the selection of the appropriate segment(s) and generic marketing strategies in a Bahraini context (one of the Gulf Cooperation Council (GCC) members).

\section{Literature Review}

The process of market selection to be, later on, targeted by the appropriate marketing strategy(s) starts by a successful segmentation phase. There are many variables enhancing that segmentation phase like well designed planning (Weinstein, 1987), commitment and involvement of senior managers (Engle et al., 1972), choice of segmentation bases (Coles \& Culley, 1986), readiness to respond to market changes (Brown et al., 1989), creative thinking (Weinstein, 1994), clearly-defined objectives and organization using a multi-functional project team, considering past research, promotion and market trends (Haley, 1984). Dibb (1998) has documented many cases where segmentation had failed, such as: (1) if segmentation results in unpractical solution which could not be implemented, (2) poor understanding of segmentation principles,(3) inappropriately oriented literature, and (4) lack of practical implementation guidance.

For generic marketing strategies, Banker et al. (2014); Baack and Boggs (2008); Purba (2002); Zhao et al. (2002); Erto and Vanacore (2002); Gopalakrishna and Subramanian (2001); Hofstede (2001); Groom and David (2001); Mattila (1999); Porter (1998); Donthu and Yoo (1998); Piercy et al. (1998); Wit et al. (1998); Tax and Brown (1998); Tyson (1997); Cotter et al. (1997); Katsikeas and Leonidou (1996); Reeves and Bednar (1994); James et al. (1994); Malhotra et al. (1994); Desatnick and Detzel (1993); Myers (1993); Olusoga (1993); Hooley and Saunders (1993); Babakus and Boller (1992); Cronin and Taylor (1992); Bergstrom (1992); Bolton and Drew (1991); Berry and Parasuraman (1991); Chardwick (1991); Heskett et al. (1990); Lee and Yang (1990); Kim et al. (1989); Albaum et al. (1989); Fornell and Wernerfelt (1988); Hill, (1988); Murray (1988); Parasuraman et al. (1985); Fornell and Wernerfelt (1984); Clarke (1984); Hauser and shugan (1983); Malickson (1983); Piercy (1982); Rugman (1979); IMR (1978); ITI (1979); BETRO Trust Committee (1976); and Smith (1956) have contributed to definitions of generic marketing strategies. Together they have identified business intelligence strategy, customers service strategy, customer complaint management strategy, Aikido strategy, free telephone line strategy, focus strategy or market concentration, differentiation strategy, or market diversification, and cost leadership strategy as basic marketing strategies. One of the objectives of the current study is limiting the coverage on testing the factors for selecting only three of these generic marketing strategies i.e. focus, differentiation, and cost leadership, as shown in Figure 1.

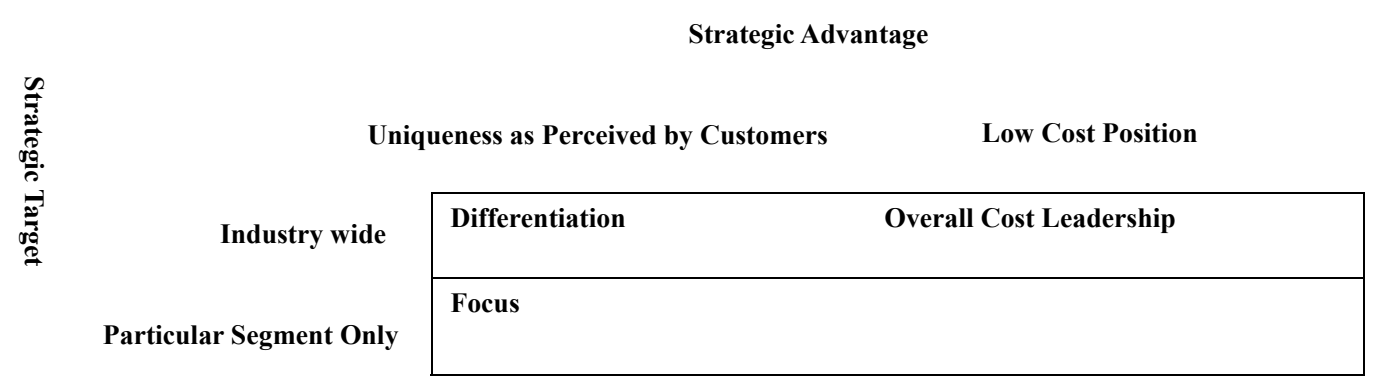

Figure 1. Porter's generic strategies

Source: Adopted from Porter (1980, p. 39).

Firstly, focus strategy is built around serving a few specific segments or markets in that geographic scope, and 
the channeling of resources into these segments with the objective of securing significant market share, which in turn can enhance long-term profitability (Collins and Winrow, 2010; Kotler, 2003; Albaum et al., 1989; Piercy, 1982; ITI, 1979; Tessler, 1977; Day, 1976; BETRO Trust Committee, 1976; Tookey, 1975). Proponents of focus strategy (e.g., Elbrese, 2008; Anderson, 2006, Albaum et al., 1989; Piercy, 1982; ITI, 1979; BETRO Trust Committee, 1976) argued that market specialization, economy of scale, greater market knowledge, high degree of control, and increased profitability by servicing a small, but demanding customer base, willing to pay a premium price for its unique product are viable benefits from adopting such strategy. In this perspective Elbrese, (2008) found that while the "tail" (representing unique, customized offerings) in potential demand volume is indeed long, it is also flat. In fact, the explanation offered by these researchers' group is that by securing large market shares in a few key markets, firms using focus strategy are able to generate higher performance results than firms using diversification strategy. However, Olusoga's (1993) and Clarke's (1984) findings disproved many of these benefits, as their findings did not support the notion advanced by market concentration proponents that by concentrating on a few, carefully selected markets, most firms can generate superior performance results. More specifically, there is no evidence that focus had a positive effect on the average level of profit margins in the period from 1970 to 1976 in UK manufacturing industry (Clarke, 1984, p. 66).

It is worth noting that the differences between focus and differentiation strategies rest in the number of target markets that each strategy intends to serve. The latter targets several strategic markets at a time. The former concentrates on one or few markets. The resources required for focus strategy are relatively low compared with that required for differentiation strategy (Adel-Reheem, 1984). It is claimed that both cost leadership and differentiation are about how to compete, while focus is about where to compete (Faulkner and Bowman, 1992). Therefore, the focuses on the pricing factor across the three generic strategies are different. In cost leadership strategy, it is the main tool for reaping the competitive edge in the target market. Whilst pricing is one effective tool [along with the other elements of marketing programs (i.e. the marketing and the promotional mixes)] that could be used in the target markets by both the differentiators and the concentrators. The question that the current study aims at finding an appropriate answer for is "what are the variables behind selecting focus strategy in Bahraini (domestic and MNCs) context?" As shown in Figure 2.

Secondly, a differentiation strategy exists when a business distinguishes its product from its competitors with unique non-price attributes that are perceived by the consumer as better than the viable alternatives (Collins \& Winrow, 2010, p. 309). In this perspective, Bailey et al. (2007); and Kim et al. (2004) have argued about the role of e-shopping in creating a non-price differentiation value by offering another visual selling avenue in the competition in the digital age nowadays. Moreover, differentiation strategy (termed "market spreading" by Albaum et al., 1989, and Piercy, 1982 and "market diversification by Olusoga, 1993) is defined as the allocation of resources over a large number of markets in an attempt to reduce risks of concentrating resources and to exploit the economies of flexibility (Albaum et al., 1989, p. 105) through using a low commitment of resources to many markets at the same time (Bradley \& Gannon, 2000, p. 14). Differentiation strategy intends to strengthen the image of a company by selling unique offers, as these offers are characterized by valuable features (e.g. quality, customer orientation, location, design, and integration). To pledge an additional value to the customer which he/she rewards by paying an instant higher price (Corsten \& Will, 1993, p. 316) as well as remaining loyal to the brand name (Westphal, 1999). Therefore, it implies serving many target markets throughout different marketing programs as a result of accurate segmentation (Kotler, 2003; Adel-Reheem, 1984). Recently, Banker et al. (2014) added that firms adopting the differentiation strategy achieve a competitive advantage by investing in developing products or services that offer unique qualities desirable to customers which allow the firm to command a price premium.

Most Recently, Banker et al. (2014) have argued about the benefits of perusing a differentiation strategy in achieving sustainable financial performance more than that achieved via perusing a cost leadership strategy. However, a differentiation strategy may also be associated with greater risk. In their research, they have indicated that both cost leadership and differentiation strategies have a positive impact on contemporaneous performance. However, the differentiation strategy allows a firm to sustain its current performance in the future to a greater extent than a cost leadership strategy. It worth mentioning, also here, that the variables behind the selection of these two generic marketing strategies were not tested. Consequently, the current research is motivated by investigating the sets of variable in this perspective, as shown in Figure 2.

Finally, cost leadership strategy aim at increasing market share based on creating a low-cost position relative to their counterparts. Firms can adopt different resource allocation methods to achieve cost leadership such as large-scale facilities, process improvements, cost minimization, total quality management (TQM), benchmarking, and overhead control (Banker et al., 2014), aggressive construction of efficient-scale facilities, vigorous pursuit 
of cost reductions from experience, tight cost and overhead control, avoidance of marginal customer accounts, and cost minimization in areas like R\&D, service, sales force, advertising, and so on" (Porter, 1980, p. 35). Cost leadership strategy was increasingly common in the 1970s because of the popularization of the experience curve concept (Porter, 1980). It is more concerned with process efficiency to achieve the status of the lowest-cost producer or supplier to its market (Partridge \& Perren, 1994; Reitsperger et al., 1993). To sum up, cost leadership strategy is aimed at a relative cost advantage over competitors in the relevant market segment by concentrating all strategic activities on cost reduction (Corsten \& Will, 1993, p. 316). It requires tight control on all kinds of costs, as well as efficient usage of resources in comparison with competitors. Recently, Baack and Boggs, (2008), have focused on the globally effectiveness of cost Leadership as they tried to answer a simple question which is "How effective is this generic strategy for MNCs from developed nations operating in emerging market economies?" They did find that developed-country MNCs may find a consistently applied global cost strategy unrewarding, as emerging markets are unique environments with unique needs (Arnold \& Quelch, 1998). Therefore, cost leadership is rarely an effective strategy in emerging markets when applied by MNCs from developed nations, and that different strategies may be necessary for different environments. As shown in Figure (2), the current study is an endeavor to figure out these detailed variables behind the selection of differentiation strategy.

For the factors affecting the selection of target markets, Hooley and Saunders (1993); Day (1986); Patel and Younger (1978); and Robinson et al. (1978) have amplified and extended the factors that should be considered whenever determining the target market. These are: (a) market factors e.g. the size of the target market, growth rate in that target market, stage of industry evolution, predictability, price elasticity and sensitivity, bargaining power of customers, and seasonality and cyclicality of demand; (b) economic and technological factors e.g. barriers to entry, barriers to exit, bargaining power of suppliers, level of technology utilization, investment required, and margins available; (c) competitive factors e.g. competitive intensity, quality of competition, threat of substitution, and degree of differentiation; and (d) environmental factors e.g. exposure to economic fluctuations, exposure to political and legal factors, degree of regulation, social acceptability and physical environment impacts. The current study is an endeavor to validate these main and sub-variables in a Bahraini context, as shown in Figure 2.

In this perspective, Malhotra et al. (2009) have discussed distance factors and target market selection. They have tested target market selection of multinational firms. These variables were the cultural, administrative, geographic, and economic distance framework as originally proposed by Ghemawat (2001). More specifically, cultural distance refers to differences in social norms, language, and beliefs between the two countries. Administrative distance refers to differences in bureaucratic, working, and political structure prevalent in the two countries. Geographic distance refers to the actual distance in miles or kilometers between the countries. Finally, economic distance refers to differences in economic conditions between the two countries (Malhotra et al., 2009, p. 654). The experience of firms from 18 emerging countries between 1990 and 2006 were utilized for that purpose. They found positive significant relationships between administrative and economic as distance factors and the number of cross-border acquisitions (CBAs). However, negative significant relationship between cultural and geographic as distance factors and (CBAs) were found. Their results added up fuel to the inconsistence debates in this area. More specifically, Buckley et al. (2007); Clark and Pugh (2001); Dow (2000); and Edwards and Buckley (1998) have found that cultural and geographic distances have a significant impact on firms' decisions to select international markets. On the other hand, Mitra and Golder (2002); Robertson and Wood (2001); and Terpstra and Yu (1988) find no impact of cultural and geographic distance on firms' selection of international markets. Despite the fact that the current study testing one factor of Ghemawat's model e.g. economic, the details of that economical factor comes from Hooley and Saunders (1993) that been adopted from Abell and Hammond (1979), as appears in Appendix (A).

Also, Voola, and O'Cass, (2010), have discussed the strategy implementation and the resource-based view of the firm ( $\mathrm{RB}$ theory) to investigate the relationships among competitive strategies (i.e. differentiation and cost-leadership), responsive market orientation (RMO), proactive market orientation (PMO) and firm performance. The experience of 189 response base were utilized to find out that both competitive strategies influence RMO and PMO, which then influence firm performance. However, the results show that differentiation strategy has a stronger influence on RMO and PMO than cost-leadership strategy, and that PMO has a stronger influence on performance than RMO. Finally, Zahay and Griffin (2010) have discussed marketing selection metrics and performance. Life time value and retention were the customer-based measures deployed in their study. In the same context, Ramani and Kumar (2008) argued that most of the recent trends are to look at customer-based measures in addition to traditional financial measures to capture the results of marketing efforts 
and to examine the ability of a firm to interact with and develop relationships with its customers. They adopted Porter's $(1980,1985)$ framework which claims that two fundamental market positions for theoretically maximizing profits are to position the unit to achieve lower costs or to increase revenues through differentiation. Low-cost business units minimize costs and pass those savings on in the form of lower prices. Differentiators offer something unique (product, service component, geographic location) for which they charge a price premium. It worth mentioning that positioning is how the business unit delivers value to its customers and wants them to think of its products and service, relative to other offerings in the market, consequently Kalafatis et al., (2000); Kotler and Keller, (2008); Hooley et al. (1998) have considered positioning a fundamental marketing management decision. They added that after the positioning choice has been made, segmentation involves deciding which customer' groups best fit with the chosen position (Zahay \& Griffin, 2010, p. 85). Such decisions i.e. segmenting and positioning are basic to the operation of all businesses and the majority of marketing managers' time spent in these arenas (Porter, 1980, 1985).The experience of 30 managers were utilized to understand how business units manage customer information and then used in designing the study survey. A phone survey sample size of 209 respondents (109 from insurance industry and 100 from industry) were used. They found the following results; a positive and significant correlation between customer-based performance and business growth is existed, and differentiators are better than low-cost. At the end of that generic marketing strategies' literature, the current study proposed the underneath model in which the relations amongst its components will be explored in a Bahraini context, as shown in Figure 2.

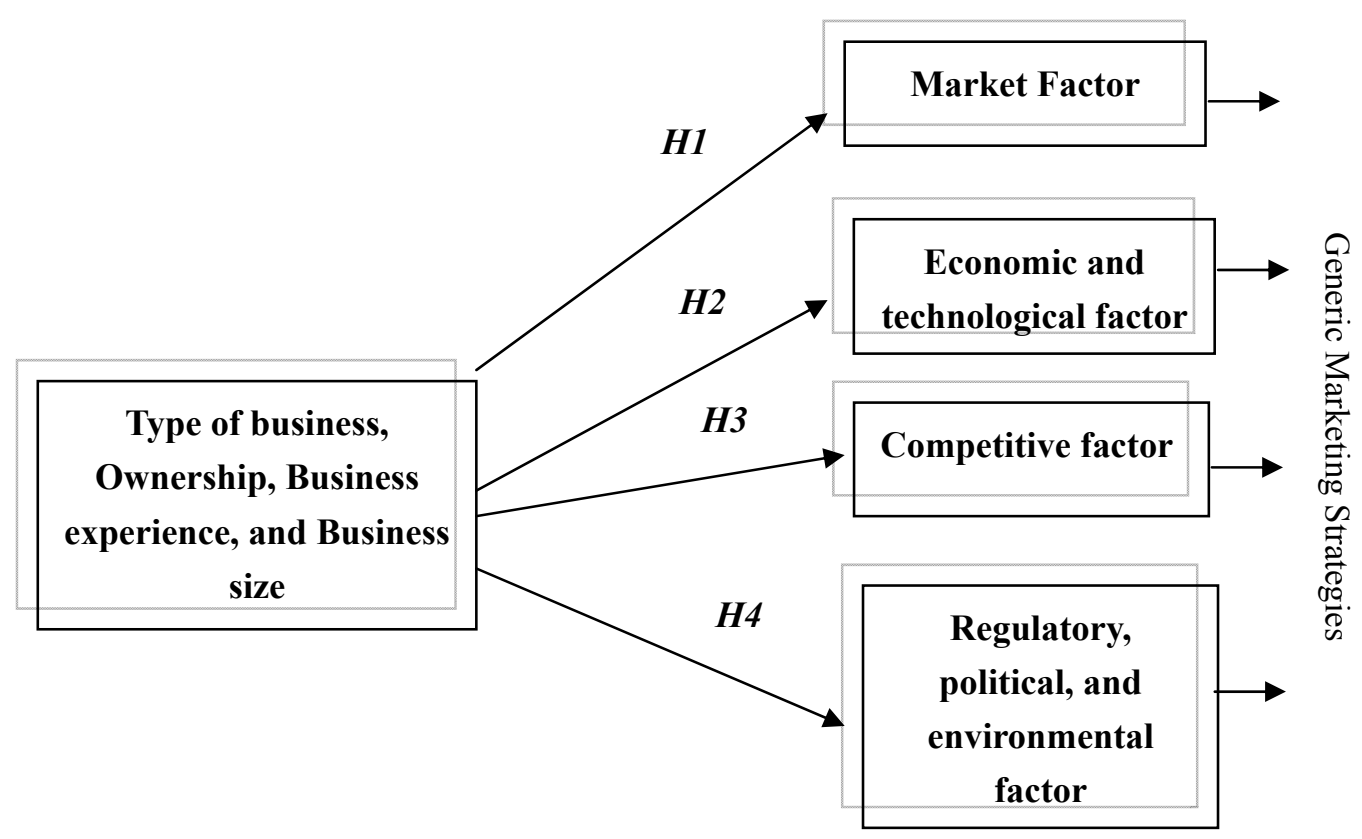

Figure 2. The study's suggested model

\section{Research Objectives}

The current study aims at achieving the followings:

1) Exploring target markets selection's variables in a Bahraini context;

2) Exploring marketing strategies selection's variables;

3) Exploring causality relationships between study's demographics (i.e. type of business, ownership, business experience, and business size) and "market", "economical and technological", "competitive", and "regulatory, political, and environmental" factors.

\section{Research Hypotheses}

The following hypotheses are proposed to achieve the study's objectives:

H1: There is a significant causality relationship between demographics (i.e. type of business, ownership, 
business experience, and business size) and "market factor";

H2: There is a significant causality relationship between demographics (i.e. type of business, ownership, business experience, and business size) and "economic and technological factor";

H3: There is a significant causality relationship between demographics (i.e. type of business, ownership, business experience, and business size) and "competitive factor"; and

H4: There is a significant causality relationship between demographics (i.e. type of business, ownership, business experience, and business size) and "regulatory, political, and environmental factor".

\section{Study Methodology}

This part includes the followings: (1) determining the deployed research paradigm (2) the population from which a representative sample was selected; (3) data collection method; (4) statistical packages and statistical techniques deployed in the current study. Firstly; for research paradigm, a positivistic approach through using a structured questionnaire was adopted. Secondly, a convenience sample of 177 Bahraini' marketers and general managers working for domestic companies and multinational corporations (MNCs) has been utilized in the current study. Thirdly, a three parts (i.e. demographics, target market selection and marketing strategies variables) structured questionnaire with five-point Likert scale was deployed and filled by marketing and general managers in Bahraini context, as shown in Appendix (A). These three parts are; (1) demographic variables; (2) target market selection's variables (from X1 to X22) and marketing strategies selection's variables (from X23 to X90). Demographics include type of business, ownership, business experience, and business size. Target market selection's variables are market (from X1 to X7 averaged by A), economical and technological (from X8 to X13 and averaged by B), competitive (from X14 to X17 and averaged by C), and environmental factors (from X18 to X22 and averaged by D). Marketing strategies selection's variables are market factors that includes size (from X23 to X25 and averaged by A1), growth rate (from X26 to X28 and averaged by A2), stage of industry evolution (from X29 to X32 and averaged by A3), market predictability (from X33 to X35 and averaged by A4), price elasticity (from X36 to X38 and averaged by A5), customer bargaining power (from X39 to X41 and averaged by A6), and seasonality and cyclicality (from X42 to X45 and averaged by A7). Economical and technological factors that includes barriers to entry (from X46 to X48 and averaged by B1), barriers to exit (from X49 to X51 and averaged by B2), bargaining power of suppliers (from X52 to X54 and averaged by B3), level of technology utilization (X55 and X56 and averaged by B4), investment required (from X57 to X59 and averaged by B5), and margins available (from X60 to X62 and averaged by B6). Competitive factors includes completion intensity (from X63 to X65 and averaged by C1), quality of competition (from X66 to X69 and averaged by C2), threat of substitution (from X70 to X73 and averaged by C3), and degree of differentiation (X74 and X75 and averaged by C4). Environmental factors include exposure to economic fluctuations (from X76 to X78 and averaged by D1), exposure to political and legal factors (from X79 to X81 and averaged by D2), degree of regulation (from X82 to X84 and averaged by D3), social acceptability (from X85 to X87 and averaged by D4), and physical environment (from X88 to X90 and averaged by D5). The questionnaire coupled with the covering letter explaining the research objectives were handled to every response base (i.e. general and marketing managers in Bahraini businesses both domestics and international). The response rate was 70.8 percent, as the completed and returned questionnaires were 177 out of 250 questionnaires. Finally, SPSS release twenty one was used as a data analysis package. Descriptive analysis (e.g. percentages, mean, standard deviation, and variance), factor analysis (principal component with a Varimax Rotation), and multiple regression were deployed as analytical statistical techniques.

\section{The Study Findings}

In this part of the study, sample normality, regressors multi-collinearity, scale validity, reliability, hypotheses testing, conclusion and recommendations will be discussed.

\subsection{Normality, Multi-Collinearity, Validity, and Reliability.}

Data distribution's shape is considered normal when the sample size is bigger than 30 cases (Ortuzar \& Willumsen, 1994). Consequently, normality dimension is assumed, as sample's size is 177 cases in the current study. Statistically, instrument and concepts are considered reliable when the value of Cronbach alpha coefficient is bigger than 60 percent (Foster, 2001, p. 228; Teo \& King, 1996; Malhotra, 1993, p. 308). In the current study instrument Cronbach alpha's coefficient is 70.6 percent, therefore reliability dimension in the current study is supported. Multi-collinearity amongst study's regressors is supported, as all correlations' coefficients show values less than unity, as shown in Table 1. For instrument's validity, grouped discussions with colleagues and fellow academics suggested some minor paraphrasing and typo amendments. 
Table 1. Multi-collinearity of regressors

\begin{tabular}{lllll}
\hline \multirow{2}{*}{ Independent Variables } & \multicolumn{4}{l}{ Independent Variables } \\
\cline { 2 - 5 } & Business & Ownership & Experience & Size \\
\hline$>\quad$ Business & $\ldots$. & & & \\
$>\quad$ Ownership & 0.262 & $\ldots$. & & \\
$>\quad$ Experience & 0.345 & 0.045 & $\ldots$. & \\
$>\quad$ Size & 0.230 & 0.450 & $0 . .279$ & $\ldots .$. \\
\hline
\end{tabular}

Note. Number of matrix's cells $=\mathrm{n}(\mathrm{n}-1) / 2$, where $\mathrm{n}=$ Number of independent variables $\{4(4-1) / 2=\mathbf{6}\}$ Variables.

\subsection{Hypotheses Testing}

Based on factor analysis's results, the target market selection variables are loaded on four factors and all item factor loadings were greater than 0.50 expect for stage of industry evolution item and social acceptability item that reports 0.493 and 0.468 respectively, as shown in Table (2). Also, the four factors repot an Eigenvalue greater than unity. These four variables are "market", "economic and technological", "competitive", and "regulatory, political and environmental factors", as shown in Table 2. The result in this perspective goes hand in hand with (Hooley \& Saunders, 1993) that been adopted from Abell and Hammond (1979), as it loads the 22 items in four factors too, however the title of the fourth factor has become "regulatory, political, and environmental" instead of only "environmental factor" as in Hooley and Saunders (1993) did name in their own study. The logic behind that change could be the content of that factor that includes regulations prevailing in that market besides social acceptability, political and legal items, and both physical environment and fluctuation in economic status.

Table 2. Factor analysis of study' concepts (rotated component matrix)

\begin{tabular}{|c|c|c|c|c|c|}
\hline & & \multicolumn{4}{|c|}{ Number of Factors } \\
\hline & & (1) & (2) & (3) & (4) \\
\hline 1. & Size & .578 & & & \\
\hline 2. & Growth & .586 & & & \\
\hline 3. & Stage of Industry Evolution & .493 & & & \\
\hline 4. & Predictability & .642 & & & \\
\hline 5. & Price Elasticity & .727 & & & \\
\hline 6. & Bargaining Power of & 726 & & & \\
\hline 7. & Seasonality and Cyclicality & .721 & & & \\
\hline 8. & Barriers to entry & & .784 & & \\
\hline 9. & Barriers to exit & & .782 & & \\
\hline 10. & Bargaining power of suppliers & & .697 & & \\
\hline 11. & Level of technology utilization & & .555 & & \\
\hline 12. & Investment required & & .787 & & \\
\hline 13. & Margins available & & .615 & & \\
\hline 14. & Competitive intensity & & & .608 & \\
\hline 15. & Quality of competition & & & .630 & \\
\hline 16. & Threat of substitution & & & .819 & \\
\hline 17. & Degree of differentiation & & & .622 & \\
\hline 18. & Exposure to economic fluctuations & & & & .534 \\
\hline 19. & Exposure to political and legal factors & & & & .812 \\
\hline 20. & Degree of regulation & & & & .616 \\
\hline 21. & Social acceptability. & & & & .468 \\
\hline 22. & Physical environment impacts & & & & .521 \\
\hline
\end{tabular}

The titles of the four factors remains as in Hooley and Saunders (1993) that been adopted from Abell and Hammond , 1979, therefore, (1) titled as market factor, (2) titled as economic and technological factor, (3) titled as competitive factor, and (4) titled as regulatory, political, and environmental factor.

$>$ Extraction Method: Principal Component Analysis; and

$>$ Rotation Method: Varimax with Kaiser Normalization. 
As shown in Table 3 and based on Multiple Regression (MR) results, there is no significant causality relationship between demographics (i.e. type of business, ownership, experience, and size) and market factor, as $p=0.601$ > 0. 05. Meanwhile, there is a significant causality relationship between demographics and "economic and technological factor", as $p=0.000<0.05$. Also, the study reports significant causality relationship between demographics and "competitive factor", as $p=0.037<0$. 05. Moreover, there is a significant causality relationship between demographics and "regulatory, political, and environmental factor", as $p=0.037<0.05$.

Consequently, the alternative hypotheses $\boldsymbol{H}_{2}, \boldsymbol{H}_{3}$, and $\boldsymbol{H}_{4}$ are supported. However, the alternative hypothesis $\boldsymbol{H}_{\boldsymbol{1}}$ is not supported. In this perspective, the most remarkable things here are:

- Data entry order process did not affect on its analysis, as Durbin-Watson test reported values $>1.4$ for all dependent variables, as shown in Table ).

- The explanation powers of these three positive models (i.e. the supported hypotheses) represented by "R square" and "adjusted R square" are low, as they reported values like 12.5, 5.7, and 5.7 percent and 10.5, 3.5, and 3.5 percent for "R square" and "adjusted R square" respectively. Consequently, other variables could be explored by other researchers rather than the demographics in the current study, as shown in Table 3 . Therefore, other researchers are invited to explore other variables rather than those been tested in the current study.

Table 3. Multiple regressions between demographics (IVs) and market, economic and technological, competitive, and regulatory, political and environmental factors (DVs)

\begin{tabular}{|c|c|c|c|c|c|c|}
\hline (Regressors or IVs) & $\mathbf{F}$ & P-value & $\mathbf{R}$ & $\begin{array}{l}\mathbf{R} \\
\text { Square }\end{array}$ & $\begin{array}{l}\text { Adjusted R } \\
\text { Square }\end{array}$ & $\begin{array}{l}\text { Durbin-W } \\
\text { atson }\end{array}$ \\
\hline Market Factor & 0.698 & 0.601 & 0.125 & 0.0157 & -0.007 & 2.094 \\
\hline Economic and Technological Factor & 6.196 & $0.000 * * *$ & 0.354 & 0.125 & 0.105 & 2.060 \\
\hline Competitive Factor & 2.606 & $0.037 * * *$ & 0.239 & 0.057 & 0.035 & 1.867 \\
\hline Regularity, Political, and Environmental Factor & 2.606 & $0.037 * * *$ & 0.239 & 0.0571 & 0.035 & 1.867 \\
\hline
\end{tabular}
Notes.

$>(* * *)$ There is a significant relationship between at least one of the independent variables and model dependent variable as $p<0.05$.

$>\mathbf{R}$ Square $=$ indicates the effect the independent variables have on the dependent one in the sample.

$>$ Adjusted R Square $=$ reflects the model goodness of fit for the population.

Durbin-Watson is a test to indicate the effect of data entry order in the analysis, therefore if it is $>1.4$ it means the order has no effect on the analysis and if it is less, it means the order has affected the analysis (Stat graphics 2000).

For the factors affecting marketing strategies' selection and based on univariate analysis as shown in Table 4, focus strategy is preferred whenever market size and growth rate are medium, high market predictability low price elasticity, high bargaining power of customer, no seasonality and cyclicality, huge entry barriers, with huge and small exit barriers, low bargaining power of suppliers, advanced technology been utilized in that market, huge investments are required. Also, focus strategy is preferred whenever low margin is available in the target market, for markets with both severe and low levels of competition, with threat of substitution in the foreseeable future, with both differentiated and undifferentiated markets. Moreover, focus strategy is preferred with highly and medium economically fluctuated markets, with markets semi-stable political and legal, with highly and medium regulated markets, with highly accepted companies, and with markets with excellent and bad physical environment.

Differentiation strategy is preferred whenever market size is big, market's growth rate is medium, industry's evolution's stages are in introduction, in growth, and in maturity. Also, differentiation is preferred with medium market predictability, with medium price elasticity, and with high bargaining power of customer. Moreover, differentiation is preferred with two seasons (i.e. summer and winter), with three seasons (i.e. summer, winter and spring), and with four seasons' markets (i.e. summer, winter, spring, and autumn).Differentiation is preferred with markets with medium entry barriers, with markets with medium exit barriers, with markets with high bargaining power of suppliers, and with markets with medium bargaining power of suppliers. Annex, differentiation is preferred with markets using old technology, with markets requiring medium, and small investments, with high and medium margin's markets, with markets with medium level of competition, with 
product centered competition, distribution centered competition, with markets exposed to threats of substitution by other items (medium threats and low threats of substitution by other items). Finally, differentiation is preferred with markets exposed to both low and high political and legal factors, with low regulated market, with medium accepted companies, and with average physical environment.

Cost leadership strategy is preferred with small markets, with high growth rate markets, with markets in the decline stage, with highly and low predictable markets, with markets with high price elasticity, with markets with low bargaining power of customer, with markets having small entry barriers, with markets require small investments, with markets with low margin, with markets with severe level of competition, and with markets with both price centered and promotion centered competition.

Table 4. Factors affecting marketing strategies' selection

\begin{tabular}{|c|c|c|c|c|c|c|}
\hline Marketing Strategy Selection Factors & Focus & Differentiation & $\begin{array}{l}\text { Cost } \\
\text { Leadership }\end{array}$ & Mean & $\begin{array}{l}\text { Std. } \\
\text { Deviation }\end{array}$ & Variance \\
\hline \multicolumn{7}{|l|}{ A-Market Factors } \\
\hline \multicolumn{7}{|l|}{ 1-Size } \\
\hline Big Market & & $44.1 \%$ & & 2.09 & .756 & .571 \\
\hline Medium Market & $50.8 \%$ & & & 2.25 & .681 & .463 \\
\hline Small Market & & & $47.5 \%$ & 1.78 & .867 & .752 \\
\hline \multicolumn{7}{|l|}{ 2-Growth Rate } \\
\hline$>\quad$ High growth rate markets & & & $35.6 \%$ & 2.03 & .825 & .681 \\
\hline$>\quad$ Medium growth rate markets & & $47.5 \%$ & & 2.02 & .727 & .528 \\
\hline$>\quad$ Low growth rate markets & $49.4 \%$ & & & 1.75 & .817 & .668 \\
\hline \multicolumn{7}{|l|}{ 3-Stage of Industry Evolution } \\
\hline$>\quad$ Introduction Stage & & $40.7 \%$ & & 1.81 & .749 & .562 \\
\hline$>\quad$ Growth Stage & & $44.1 \%$ & & 1.95 & .748 & .560 \\
\hline$>\quad$ Maturity Stage & & $50.8 \%$ & & 1.98 & .703 & .494 \\
\hline Decline Stage & & & $40.7 \%$ & 2.05 & .874 & .764 \\
\hline \multicolumn{7}{|l|}{ 4-Predictability } \\
\hline$>\quad$ High Market Predictability & $35.6 \%$ & & $35.6 \%$ & 2.00 & .846 & .716 \\
\hline$>\quad$ Medium Market Predictability & & $42.4 \%$ & & 1.90 & .754 & .569 \\
\hline$>\quad$ Low Market Predictability & & & $39 \%$ & 2.05 & .855 & .730 \\
\hline \multicolumn{7}{|l|}{ 5-Price Elasticity } \\
\hline$>\quad$ High Price Elasticity & & & $44.1 \%$ & 2.15 & .842 & .710 \\
\hline$>\quad$ Medium Price Elasticity & & $47.5 \%$ & & 1.92 & .722 & .521 \\
\hline Low Price Elasticity & $39 \%$ & & & 1.95 & .855 & .730 \\
\hline \multicolumn{7}{|l|}{ 6-Bargaining Power of Customer } \\
\hline$>\quad$ High Bargaining Power of Customer & $39 \%$ & $39 \%$ & & 1.98 & .815 & .664 \\
\hline Medium Bargaining Power of Customer & & $45.8 \%$ & & 1.80 & .710 & .504 \\
\hline$>\quad$ Low Bargaining Power of Customer & & & $40.7 \%$ & 2.02 & .895 & .801 \\
\hline \multicolumn{7}{|l|}{ 7-Seasonality and Cyclicality } \\
\hline$>\quad$ No Seasonality and Cyclicality & $44.1 \%$ & & & 1.80 & .800 & .640 \\
\hline$>\quad 2$ Seasons and Cycle (Summer and Winter) & & $47.5 \%$ & & 1.75 & .681 & .463 \\
\hline$>3$ Seasons and Cycle (Summer, Winter and & & $54.2 \%$ & & 2.02 & .678 & .460 \\
\hline \multicolumn{7}{|l|}{ Spring) } \\
\hline$>\quad 4$ (Summer, Winter, Spring, and Autumn ) & & $50.8 \%$ & & 2.05 & .701 & .492 \\
\hline \multicolumn{7}{|l|}{ B-Economic and Technological Factors } \\
\hline \multicolumn{7}{|l|}{8 -Barriers to entry } \\
\hline$>\quad$ Huge Entry Barriers & $54.2 \%$ & & & 1.66 & .797 & .634 \\
\hline$>\quad$ Medium Entry Barriers & & $50.8 \%$ & & 1.95 & .701 & .492 \\
\hline$>\quad$ Small Entry Barriers & & & $42.4 \%$ & 2.14 & .835 & .697 \\
\hline \multicolumn{7}{|l|}{ 9-Barriers to exit } \\
\hline$>\quad$ Huge Exit Barriers & $44.1 \%$ & & & 1.88 & .868 & .753 \\
\hline Medium Exit Barriers & & $55.9 \%$ & & 2.00 & .666 & .443 \\
\hline$>\quad$ Small Exit Barriers & $39 \%$ & & & 1.97 & .865 & .749 \\
\hline \multicolumn{7}{|l|}{ 10-Bargaining power of suppliers } \\
\hline$>\quad$ High Bargaining Power of Suppliers & & $39 \%$ & & 2.07 & .780 & .609 \\
\hline$>\quad$ Medium Bargaining Power of Suppliers & & $45.8 \%$ & & 2.00 & .739 & .545 \\
\hline$>\quad$ Low Bargaining Power of Suppliers & $45.8 \%$ & & & 1.93 & .921 & .848 \\
\hline 11-Level of technology utilization & & & & & & \\
\hline
\end{tabular}




\begin{tabular}{|c|c|c|c|c|c|c|c|}
\hline $\begin{array}{l}> \\
\mathrm{Ma}\end{array}$ & $\begin{array}{l}\text { Advanced Technology been utilized in that } \\
\text { et }\end{array}$ & $42.4 \%$ & & & 1.83 & .808 & .653 \\
\hline$>$ & Old Technology been utilized in that Market & & $42.4 \%$ & & 2.00 & .761 & .580 \\
\hline \multicolumn{8}{|c|}{ 12-Investment required } \\
\hline$>$ & Huge Investments are Required & $40.7 \%$ & & & 1.93 & .863 & .745 \\
\hline$>$ & Medium Small Investments are Required & & $47.5 \%$ & & 1.95 & .725 & .526 \\
\hline$>$ & Small Investments are Required & & & $39 \%$ & 2.07 & .843 & .711 \\
\hline \multicolumn{8}{|c|}{ 13-Margins available } \\
\hline$>$ & High Margin is Available & & $42.5 \%$ & & 1.93 & .758 & .575 \\
\hline$>$ & Medium Margin is Available & & $39 \%$ & & 1.90 & .777 & .603 \\
\hline$>$ & Low Margin is Available & $37.3 \%$ & & $37.3 \%$ & 2.00 & .866 & .750 \\
\hline \multicolumn{8}{|c|}{$\mathrm{C}$ - Competitive factors } \\
\hline \multicolumn{8}{|c|}{ 14-Competitive intensity } \\
\hline$>$ & Severe Level of Competition & $33.9 \%$ & & $33.9 \%$ & 2.00 & .826 & .682 \\
\hline$>$ & Medium Level of Competition & & $54.2 \%$ & & 1.85 & .661 & .437 \\
\hline$>$ & Low Level of Competition & $44.1 \%$ & & & 1.93 & .902 & .814 \\
\hline \multicolumn{8}{|c|}{ 15-Quality of competition } \\
\hline$>$ & Price Centered Competition & & & $54.2 \%$ & 2.31 & .831 & .690 \\
\hline$>$ & Product Centered Competition & & $44.1 \%$ & & 2.08 & .745 & .555 \\
\hline$>$ & Distribution Centered Competition & & $45.8 \%$ & & 2.00 & .739 & .545 \\
\hline$>$ & Promotion Centered Competition & & & $37.3 \%$ & 2.10 & .798 & .637 \\
\hline \multicolumn{8}{|c|}{ 16-Threat of substitution } \\
\hline & $\begin{array}{l}\text { No Threat of Substitution is existed in the } \\
\text { eeable future }\end{array}$ & $42.4 \%$ & & & 1.83 & .808 & .653 \\
\hline$>$ & High Threats of Substitution by other Items & & $37.3 \%$ & & 1.92 & .790 & .623 \\
\hline$>$ & Medium Threats of Substitution by other Items & & $42.4 \%$ & & 1.97 & .761 & .578 \\
\hline$>$ & Low Threats of Substitution by other Items & & $52.5 \%$ & & 2.03 & 690 & .476 \\
\hline \multicolumn{8}{|c|}{ 17-Degree of differentiation } \\
\hline$>$ & Differentiated Market & $44.1 \%$ & & & 1.75 & .752 & .566 \\
\hline$>$ & Undifferentiated Market & $45.8 \%$ & & & 1.78 & .806 & .650 \\
\hline \multicolumn{8}{|c|}{ D- Environmental factors } \\
\hline \multicolumn{8}{|c|}{ 18-Exposure to economic fluctuations } \\
\hline$>$ & Highly Exposed Market & $42.4 \%$ & & & 1.85 & .822 & .675 \\
\hline$>$ & Medium Exposed Market & $44.1 \%$ & & & 1.76 & .769 & .591 \\
\hline$>$ & Low Exposed Market & & $45.8 \%$ & & 1.90 & .731 & .535 \\
\hline \multicolumn{8}{|c|}{ 19-Exposure to political and legal factors } \\
\hline$>$ & Highly Exposed to political and legal factors & & $39 \%$ & & 1.97 & .783 & .612 \\
\hline & $\begin{array}{l}\text { Medium level of Exposure to political and legal } \\
\text { s }\end{array}$ & $39 \%$ & & & 1.92 & .832 & .692 \\
\hline & $\begin{array}{l}\text { Low level of Exposure to political and legal } \\
\text { s }\end{array}$ & & $44.1 \%$ & & 1.88 & .741 & .548 \\
\hline \multicolumn{8}{|c|}{ 20-Degree of regulation } \\
\hline$>$ & Highly Regulated Market & $45.8 \%$ & & & 1.78 & .806 & .650 \\
\hline$>$ & Medium Regulated Market & $39 \%$ & & & 1.88 & .807 & .651 \\
\hline$>$ & Low Regulated Market & & $50.8 \%$ & & 2.08 & 698 & .487 \\
\hline \multicolumn{8}{|c|}{ 21-Social acceptability. } \\
\hline$>$ & Highly Accepted Companies & $44.1 \%$ & & & 1.85 & .842 & .710 \\
\hline$>$ & Medium Accepted Companies & & $39 \%$ & & 2.00 & .783 & .614 \\
\hline$>$ & Low Accepted Companies & $39 \%$ & & & 1.85 & .779 & .607 \\
\hline \multicolumn{8}{|c|}{ 22-Physical Environment Impacts } \\
\hline$>$ & Excellent Physical Environment & $45.8 \%$ & & & 1.78 & .806 & .650 \\
\hline$>$ & Average Physical Environment & & $47.5 \%$ & & 1.91 & .722 & .521 \\
\hline$>$ & Bad Physical Environment & $40.7 \%$ & & & .831 & .787 & .619 \\
\hline
\end{tabular}

\section{Conclusion, Discussions, and Recommendations}

The current study participated in the stream of marketing strategies' literature by three main contributions. First and in a GCC context, it confirms the four factors behind the process of target market(s) selection suggested by Hooley and Saunders (1993) that been adopted from Abell and Hammond (1979). As the title of every factor ought to reflect its inner items and the analysis of the fourth factor reveals environmental, political, economic 
fluctuations, and regulations items. Having said that, it is believed that the fourth factor's name could be "regulatory, political, and environmental" instead of only "environmental factor", as suggested by Hooley and Saunders (1993). Secondly, few causality relationships between study demographics (e.g. type of business, ownership, experience, and size) and "competitive factor", "economic and technological factor", and "regulatory, political, and environmental factor" were found. Meanwhile, no significant relationship was found between demographics and market factor. Finally, the detailed factors behind selecting each generic marketing strategy could be considered one of the contributions of the current study in a GCC context. In this perspective, Baack and Boggs, (2008) have suggested the need to test Porter's generic strategies in other emerging markets, to validate marketing strategies' literature in this regard, especially those MNCs from developed nations working in emerging economies. Partially, the current study has participated in that stream of literature, as the research's sample includes both domestic and foreign businesses in Bahraini market. However, that mixture in the sample could be one of the limitations of the current study. The limited size of Bahraini's market could be responsible for that mixture in fact. Therefore, it is recommended to research foreign businesses in other GCC countries in this perspective.

\section{References}

Adel-Reheem, M. A. (1984). Marketing Principles. Cairo University Press.

Afifi, A. A., \& Virginia, C. (1984). Computer-Aided Multivariate Analysis. Lifetime Learning, Belmont, CA.

Albaum, G., Strandskov, J., Duerr, E., \& Dowd, L. (1989). International Marketing and Export Management. NY: Addison-Wesley.

Anderson, C. (2006). The Long Tail: Why the Future of Business is Selling Less of More. Hyperion, New York, NY.

Arnold, D. J., \& Quelch, J. A. (1998). New Strategies in Emerging Markets. Sloan Management Review, 40(1), $7-20$.

Ayal, I., \& Zif, J. (1979). Market Expansion Strategies in Multinational Marketing. Journal of Marketing, 43, 84-94. http://dx.doi.org/10.2307/1250744

Baack, D. W., \& Boggs, D. J. (2008). The Difficulties in Using a Cost Leadership Strategy in Emerging Markets. International Journal of Emerging Markets, 3(2), 125-139. http://dx.doi.org/10.1108/17468800810862605

Babakus, E., \& Boller, G. W. (1992). An Empirical Assessment of the SERVQUAL Scale. Journal of Business Research, 24, 253-268. http://dx.doi.org/10.1016/0148-2963(92)90022-4

Bailey, J. P., Faraj, S., \& Yu, Y. L. (2007). The Road More Traveled: Web Traffic and Price competition in Internet Retailing. Electronic Markets, 17(1), 56-67.

Banker, R., Mashruwala, R., \& Tripathy, A. (2014). Does a differentiation strategy lead to more sustainable financial performance than a cost leadership strategy? Management Decision, 52(5), 872-896. http://dx.doi.org/10.1108/MD-05-2013-0282

Bergstrom, A. J. (1992). Business Intelligence: a Strategic Advantage. Bank Marketing, 24(10), 28-32.

Berry, L. L., \& Parasuraman, A. (1991). Marketing Service: Competing Through Quality. USA. New York: Free Press.

BETRO Trust Committee. (1976). Concentration on Key Markets. Royal Society of Arts, London.

Bolton, R. N., \& Drew, J. H. (1991). A Multistage Model of Customers' Assessments of Service Quality and Value. Journal of Consumer Research, 17, 375-384. http://dx.doi.org/10.1086/208564

Bradley, F., \& Gannon, M. (2000). Does the Firm's Technology and Marketing Profile Affect Foreign Market Entry? Journal of International Marketing, 8(4), 12-36. http://dx.doi.org/10.1509/jimk.8.4.12.19791

Brown, H. E., Shivishankar, R., \& Brucker, R. W. (1989). Requirements Driven Market Segmentation. Industrial Marketing Management, 18, 105-12. http://dx.doi.org/10.1016/0019-8501(89)90027-8

Chardwick, K. G. (1991). Some Caveats Regarding the Interpretation of Data from 800 Number Callers. The Journal of Consumer Marketing, 8(4), 53-59. http://dx.doi.org/10.1108/07363769110035153.

Clarke, R. (1984). Profit Margins and Market Concentration in UK Manufacturing Industry: 1970-1976. Applied Economics, 16, 57-71. http://dx.doi.org/10.1080/00036848400000006

Coles, G. J., \& Culley, J. D. (1986). Not all Prospects are Created Equal. Business Marketing, 52-58. 
Collins, M. K., \& Winrow, B. (2010). Porter's Generic Strategies as Applied Toward E-tailers Post-Leegin. Journal of Product and Brand Management, 19(4), 306-331. http://dx.doi.org/10.1108/10610421011059621

Corsten, H., \& Will, T. (1993). Reflections on Competitive Strategy and its Impact on Modern Production Concepts. Management International Review, 33(4), 315-335.

Cotter, M. J., Henley, J. J. A., \& Pelham, A. (1997). The Philosophy and Practice of Aikido: Implications for Defensive Marketing. SAM Advanced Management Journal, 62(1), 14-20.

Cronin, J., \& Taylor, S. A. (1992). Measuring Service Quality: A Re-examination and Extension. Journal of Marketing, 56(3), 55-69. http://dx.doi.org/10.2307/1252296

Day, A. J. (1976). Exporting for Profit. London: Graham and Trotman.

Day, G. S. (1986). Analysis for Strategic Market Decision. NY: West Publishing Co.

Desatnick, R. L., \& Detzel, D. H. (1993). Keep the Customer. San Francisco: Jossey-Bass Publishers.

Dibb, S. (1998). Market Segmentation: Strategies for Success. Marketing Intelligence \& Planning, 16(7), 394-406. http://dx.doi.org/10.1108/02634509810244390

Donthu, N., \& Yoo, B. (1998). Cultural Influences on Service Quality Expectations. Journal Service Research, 1, 178-186. http://dx.doi.org/10.1177/109467059800100207

Dunning, J. H. (1981). Explaining Outward Direct Investment of Developing Countries: in Support of the Eclectic Theory of International Production. In K. Kummar, \& M. McLeod (Eds.), Multinational from Developing Countries. DC. Heath and Co.

Elbrese, A. (2008). Should You Invest in the Long Tail? Harvard Business Review, 88-96.

Engle, J. F., Fiorillo, H. F., \& Cayley, M. A. (1972). Market Segmentation: Concepts and Applications. New York, NY: Holt, Rineholt and Winston.

Erto, P., \& Vanacore, A. (2002). A Probabilistic Approach to Measure Hotel Service Quality. Total Quality Management, 13(2), 165-175. http://dx.doi.org/10.1080/09544120120102405

Faulkner, D., \& Bowman, C. (1992). Generic Strategies and Congruent Organizational Structures: Some $\begin{array}{llll}\text { Suggestions. } & \text { European } & \text { Management } & \text { Journal, }\end{array}$ http://dx.doi.org/10.1016/0263-2373(92)90016-W

Fornell, C., \& Wernerfelt, B. (1984). The Vicious Circle of Consumer Complaints. Journal of Marketing, 48, 68-78. http://dx.doi.org/10.2307/1251330

Fornell, C., \& Wernerfelt, B. (1988). A Model for Customer Complaint Management. Marketing Science, 7(3), 287-299. http://dx.doi.org/10.1287/mksc.7.3.287

Gopalarkrishna, P., \& Subramanian, R. (2001). Revisiting the Pure Versus Hybrid Dilemma: Porter's Generic Strategies in a Developing Country. Journal of Global Marketing, 15(2), 61-75.

Groom, J. R., \& David, F. R. (2001). Competitive Intelligence Activity Among Small Firms. SAM Advanced Management Journal, 66(1), 12-24.

Haley, R. I. (1984). Benefit Segmentation-20 Years Later. Journal of Consumer Marketing, 5-13. http://dx.doi.org/10.1108/eb008090

Hauser, J. R., \& Shugan, S. M. (1983). Defensive Marketing Strategies. Marketing Science, 2(4), 319-359. http://dx.doi.org/10.1287/mksc.2.4.319

Heskett, J. L., Sasser, W. E., \& Hart, C. W. L. (1990). Service Breakthroughs: Changing the Rules of the Game. USA, New York, NY: Free Press.

Hill, C. W. L. (1988). Differentiation Versus Low Cost or Differentiation and Low Cost: A Contingency Framework. The Academy of Management Review, 13, 401-12. http://dx.doi.org/10.2307/258088.

Hofstede, G. (2001). Culture's Consequences (2nd ed.). Sage, London.

Hooley, G., \& Saunders, J. (1993). Competitive Positioning: The Key to Market Success. Prentice-Hall.

IMR. (1978). How British and German Industry Exports. London: Industrial Market Research (IMR) Ltd.

ITI. (1979). Barclays Bank Report on Export Development in France, Germany, and United Kingdom: Factors for International Success. London: Barclays Bank International. 
James, N. F., \& Imad. (1994). International Services Marketing: A Comparative Evaluation of the Dimensions of Service Quality between Developed and Developing Countries. International Marketing Review, 11(2), 115-122.

Katsikeas, C. S., \& Leonidou, L. C. (1996). Export Market Expansion Strategy: Differences between Market Concentration and Market Spreading. Journal of Marketing Management, 12, 113-134. http://dx.doi.org/10.1080/0267257X.1996.9964404

Kim, E., Nam, D., \& Stimpert, J. (2004). The Applicability of Porter's Generic Strategies in the Digital Age: Assumptions, Conjectures, and Suggestions. Journal of Management, 30(5), 569-589.

Kim, W. C., Hwang, P., \& Burgers, W. P. (1989). Global Diversification Strategy and Corporate Profit Performance. Strategic Management Journal, 10(1), 45-57.

Kotler, P. (1991). Marketing Management: Analysis, Planning, Implementation and Control. Prentice-Hall, Englewood Cliffs, NJ.

Kotler, P. (1994). Marketing Management: Analysis, Planning, Implementation and Control (8th ed.). Prentice-Hall, Englewood Cliffs, NJ.

Kotler, P. (2003). Marketing Management: Analysis, Planning, Implementation and Control (11th ed.). Prentice-Hall, Englewood Cliffs, NJ.

Kotler, P., \& Keller, K. (2008). Marketing Management (13th ed.). Prentice-Hall, Upper Saddle River, NJ.

Lee, C. S., \& Yang, Y. S. (1990). Impact of Export Expansion Strategy on Export Performance. International Marketing Review, 7(4), 14-51.

Long, F. (2001). A differentiation focus strategy provoked by Changing Environments: the American Life Insurance Industry Approaching Asian Americans. Management Research News, 24(1/2), 1-20. http://dx.doi.org/10.1108/01409170110782469

Malhotra, N. K., Ulgado, F. M., Agarwal, J., \& Baalbaki, I. B. (1994). International Services Marketing: A Comparative Evaluation of the Dimensions of Service Quality Between Developed and Developing Countries. International Marketing Review, 11(2), 5-15. http://dx.doi.org/10.1108/02651339410061937

Malickson, D. L. (1983). Are You Ready for a Product Recall. Business Horizons, (January/February), 31-35. http://dx.doi.org/10.1016/0007-6813(83)90062-9

Mattila, A. (1999). The Role of Culture in the Service Evaluation Process. Journal of Service Research, 1, 250-261. http://dx.doi.org/10.1177/109467059913006

McNaughton, R. B., Osborne, P., \& Imrie, B. C. (2002). Market-oriented Value Creation in Service Firms. European Journal of Marketing, 36(9), 990-1002.

Mintzberg, H. (1987). The Strategy Concept I: Five Ps for strategy. California Management Review, 30(1), 11-24.

Murray, A. I. (1988). A Contingency View of Porter's Generic Strategies. The Academy of Management Review, 13, 390-400. http://dx.doi.org/10.5465/AMR.1988.4306951

Myers, J. L. (1993). Three Keys to Competitive Intelligence. Bank Marketing, 25(8), 28-33.

Olusoga, S. A. (1993). Market Concentration Versus Market Diversification and Internationalization: Implications for MNE Performance. International Journal Review, 10(2), 40-59.

Parasuraman, A., Zeithaml, A. V., \& Berry, L. L. (1985). A Conceptual Model of Service Quality and its Implications for Future Research. Journal of Marketing, 49, 41-50. http://dx.doi.org/10.2307/1251430

Partridge, M., \& Perren, L. (1994). Developing Strategic Direction: Can Generic Strategies Help? Management Accounting (British), 72(5), 28-30.

Patel, P., \& Younger, M. (1978). A Frame of References for Strategic Development. Long Rang Planning, 11(6), $6-12$.

Piercy, N. (1982). Export Strategy: Markets and Competition. Allen and Unwin, London.

Piercy, N., Saunders, J. A., \& Hooley, G. J. (1998). Marketing Strategies and Competitive Positioning. Prentice-Hall, N.Y.

Porter, E. M. (1980). Competitive Strategy: Techniques for Analyzing Industries and Competitors. USA, New York: Macmillan Publishing Co., Inc. 
Porter, E. M. (1985). The Competitive Advantage: Creating and Sustaining Superior Performance. New York: Free Press.

Pugh, J., \& Bourgeois, L. J. (2011). Doing "strategy". Journal of Strategy and Management, 4(2), 172-179. http://dx.doi.org/10.1108/17554251111128637

Purba, S. (2002). No Business Neglecting Intelligence: There Have Been Many Approaches to Building BI Solutions, Most of Them Unsuccessful. Ivey Business Journal, 66(5), 28-30.

Reeves, C. A., \& Bednar, D. (1994). Defining Quality: Alternatives and Implications. Academy of Management Review, 19, 419-445. http://dx.doi.org/10.5465/AMR.1994.9412271805

Reitsperger, W. D., Daniel, S. J.,Tallman, S. B., \& Chismar, W. G. (1993). Product Quality and Cost Leadership: Compatible Strategies? Management International Review, 33(2), 7-22.

Robinson, S. J. Q., Hitchins, R. E., \& Wade, D. P. (1978). The Directional Policy Matrix: Tool for Strategic Planning. Long Range Planning, 11(3), 8-15.

Rugman, A. M. (1979). International Diversification and the Multinational Enterprise. Lexington Books, Lexington MA.

Smith, W. R. (1956). Product Differentiation and Market Segmentation as Alternative Marketing Strategies. Journal of Marketing, 3-8. http://dx.doi.org/10.2307/1247695

Spitzeck, H., \& Chapman, S. (2012). Creating Shared Value as a Differentiation Strategy-the Example of BASF in Brazil, Corporate Governance. The International Journal of Business in Society, 12(4), 499-513. http://dx.doi.org/10.1108/14720701211267838

Stat Graphics. (2000). Stat Graphics Manual (pp. 1-12).

Tax, S. S., \& Brown, S. W. (1998). Recovering and Learning from Service Failures. Sloan Management Review, 40(1), 75-89.

Tessler, A. (1977). Alternative Strategies and the Key Market Principle. Conference Sponsored by the London Chamber of Commerce and Industry and the Institute of Export (pp. 6-17).

Tookey, D. (1975). Export Marketing Decision. London: Penguin.

Tyson, K. W. M. (1997). Competition in the 21st Century. Ireland: Blackhall Publishing.

Voola, R., \& O'Cass, A. (2010). Implementing Competitive Strategies: The Role of Responsive and Proactive Market Orientations. European Journal of Marketing, 44(1/2), 245-266. http://dx.doi.org/10.1108/03090561011008691

Vorhies, D. W., \& Morgan, N. A. (2003). A configuration theory assessment of marketing organization fit with business strategy and its relationship with marketing performance. Journal of Marketing, 67(1), 100-115.

Weinstein, A. (1987). Market Segmentation. Chicago, IL: Probus Publishing.

Weinstein, A. (1994). Market Segmentation: Using Demographics, Psychographics and Other Niche Marketing Techniques to Predict and Model Consumer Behavior. Chicago, IL: Probus Publishing.

Westphal, L. (1999). Don’t Compete With Price-There's A Better Way Direct. Marketing, 62(4), 17-18.

Wit, B. D., Meyer, R., \& Huygens, M. (1998). Strategy: Process, Content, and Context (2nd ed.). West Publishing Company.

Zhao, X., Bai, C., \& Hui, Y. V. (2002). An Empirical Assessment and Application of SERVQUAL in a Mainland Chinese Department Store. Total Quality Management, 13(2), 241-255. http://dx.doi.org/10.1080/09544120120102478

\section{$\underline{\text { Appendix (A) }}$}

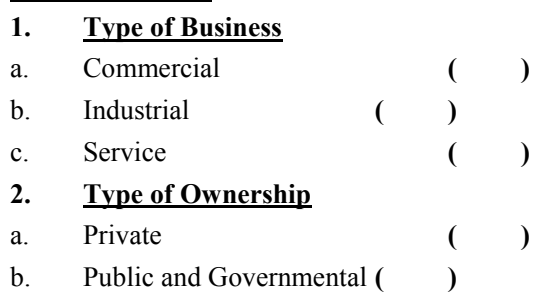


3. Business Experience

a. One year or less

b. 5 years or less

c. 10 years or less

d. 15 years or less

e. 20 years or less

f. More than 20 years or less ( )

4. Business Size

a. Large (more than 500 employees)

b. Medium (between 100-500 employees)(

c. Small (less than 100 employees)

\begin{tabular}{|c|c|c|c|c|c|}
\hline - First Target Market Selection Factors & $\begin{array}{l}\text { Strongly } \\
\text { Agree }\end{array}$ & Agree & $\begin{array}{l}\text { Do Not } \\
\text { Know }\end{array}$ & Disagree & Strongly Disagree \\
\hline
\end{tabular}

1-Market Factors (A)

Size (X1)

Growth Rate (X2)

Stage of Industry Evolution (X3)

Predictability (X4)

Price Elasticity (X5)

Bargaining Power of Customer (X6)

Seasonality and Cyclicality (X7)

B- Economic and Technological Factors (B)

Barriers to entry (X8)

Barriers to exit (X9)

Bargaining power of suppliers (X10)

Level of technology utilization (X11)

Investment required (X12)

Margins available (X13)

C- Competitive factors (C)

Competitive intensity (X14)

Quality of competition (X15)

Threat of substitution (X16)

Degree of differentiation (X17)

D- Environmental factors (D)

Exposure to economic fluctuations (X18)

Exposure to political and legal (X19)

Degree of regulation (X20)

Social acceptability. (X21)

Physical environment impacts(X22)

\begin{tabular}{llll}
\hline Second: Marketing Strategy Selection Factors & Focus 1 & Differentiation2 & Cost Leadership3 \\
\hline A-Market Factors & & & \\
1-Size (A1) & & \\
Big Market (X23) & & \\
Medium Market (X24) & & \\
Small Market (X25) & & \\
2-Growth Rate (A2) & & \\
High growth rate markets (X26) & \\
Medium growth rate markets (X27) & \\
Low growth rate markets (X28) & \\
3-Stage of Industry Evolution (A3) & \\
Introduction Stage (X29) & \\
Growth Stage (X30) & \\
Maturity Stage (X31) & \\
\hline
\end{tabular}


Decline Stage (X32)

4-Predictability (A4)

High Market Predictability (X33)

Medium Market Predictability (X34)

Low Market Predictability (X35)

5-Price Elasticity (A5)

High Price Elasticity (X36)

Medium Price Elasticity (X37)

Low Price Elasticity (X38)

6-Bargaining Power of Customer (A6)

High Bargaining Power of Customer (X39)

Medium Bargaining Power of Customer (X40)

Low Bargaining Power of Customer (X41)

7-Seasonality and Cyclicality (A7)

No Seasonality and Cyclicality (X42)

2 Seasons and Cycle (Summer and Winter) (X43)

3 Seasons and Cycle (Summer, Winter and Spring) (X44)

4 (Summer, Winter, Spring, and Autumn) (X45)

B-Economic and Technological Factors

8-Barriers to entry (B1)

Huge Entry Barriers (X46)

Medium Entry Barriers (X47)

Small Entry Barriers (X48)

9-Barriers to exit (B2)

Huge Exit Barriers (X49)

Medium Exit Barriers (X50)

Small Exit Barriers (X51)

10-Bargaining power of suppliers (B3)

High Bargaining Power of Suppliers (X52)

Medium Bargaining Power of Suppliers (X53)

Low Bargaining Power of Suppliers (X54)

11-Level of technology utilization (B4)

Advanced Technology been utilized in that Market (X55)

Old Technology been utilized in that Market (X56)

12-Investment required (B5)

Huge Investments are Required (X57)

Medium Small Investments are Required (X58)

Small Investments are Required (X59)

13-Margins available (B6)

High Margin is Available (X60)

Medium Margin is Available (X61)

Low Margin is Available (X62)

C - Competitive factors

14-Competitive intensity (C1)

Severe Level of Competition (X63)

Medium Level of Competition (X64)

Low Level of Competition (X65)

15-Quality of competition (C3)

Price Centered Competition (X66)

Product Centered Competition (X67)

Distribution Centered Competition (X68)

Promotion Centered Competition (X69)

16-Threat of substitution (C3)

No Threat of Substitution is existed in the foreseeable future

High Threats of Substitution by other Items (X71)

Medium Threats of Substitution by other Items (X72) 
Low Threats of Substitution by other Items (X73)

17-Degree of differentiation (C4)

Differentiated Market (X74)

Undifferentiated Market (X75)

D- Environmental factors

18-Exposure to economic fluctuations (D1)

Highly Exposed Market (X76)

Medium Exposed Market (X77)

Low Exposed Market (X78)

19-Exposure to political and legal factors (D2)

Highly Exposed to political and legal factors (X79)

Medium level of Exposure to political and legal factors (X80)

Low level of Exposure to political and legal factors (X81)

20-Degree of regulation (D3)

Highly Regulated Market (X82)

Medium Regulated Market (X83)

Low Regulated Market (X84)

21-Social acceptability. (D4)

Highly Accepted Companies (X85)

Medium Accepted Companies (X86)

Low Accepted Companies (X87)

22-Physical Environment Impacts (D5)

Excellent Physical Environment (X88)

Average Physical Environment (X89)

Bad Physical Environment (X90)

Notes.

$>\quad$ Focus Strategy....to serve one or few markets

$>\quad$ Differentiation Strategy....to serve many segments via unique marketing programs designed especially for each and every segment.

Cost Leadership Strategy....to control the cost items and trying to minimize them as much as you could to achieve a competitive advantage over your rivals via costs.

\section{Copyrights}

Copyright for this article is retained by the author(s), with first publication rights granted to the journal.

This is an open-access article distributed under the terms and conditions of the Creative Commons Attribution license (http://creativecommons.org/licenses/by/3.0/). 